DOI

\title{
ОЦІНКА АДАПТАЦІЙНИХ МОЖЛИВОСТЕЙ ШКОЛЯРІВ МІСТА КИЄВА 3 ЙОДОДЕФІЦИТОМ
}

\author{
๑О. А. Строй, Л. В. Сліпачук, Л. М. Казакова, Ю. П. Резніков \\ Національний медичний університет імені О. О. Богомольця
}

\begin{abstract}
РЕЗЮМЕ. Мета дослідження - вивчення адаптаційних можливостей школярів молодших класів міста Києва з підтвердженим йододефіцитом (ЙД). Проведено обстеження 50 дітей віком 6-12 років, яке передбачало визначення йодурії у разових порціях сечі з подальшим розрахунком медіани; фізичної витривалості дітей 3 визначенням індексу Руф'є; оцінку рівня функціонування системи кровообігу та ії адаптаційного потенціалу 3 розрахунком Індексу функціональних змін (ІФЗ).

Йодна недостатність виявлена у 86 \% обстежених, переважно легкого ступеня. 16 дітей (32 \%) мали індекс Руф'є нижче середнього, 29 (58 \%) - низький, у 5 школярів (10\%) був середній рівень. Дослідження ІФЗ показало, що у $90 \%$ обстежених були порушення адаптації різного ступеня вираженості.

Дослідження йодної забезпеченості показало наявність ЙД легкого та середнього ступеня у 86 \% дітей. При оцінці функціонального стану серцево-судинної системи виявлено, що 76 \% дітей мали напруження механізмів адаптації. Індекс Руф'є у 90 \% школярів не відповідав достатньому резерву системи кровообігу. Зміни функціонального стану та адаптаційних резервів серцево-судинної системи пов'язані певним чином із забезпеченістю організму йодом.

КЛЮчОВІ СЛОВА: діти, адаптація, йододефіцит.
\end{abstract}

Вступ. Як свідчать статистичні дані МОЗ України та матеріали наукових досліджень, сьогодні спостерігається тенденція до зростання загальної захворюваності, поширеності хронічних хвороб та інвалідності дітей [1]. Чинниками, що зумовлюють такі відхилення у стані здоров'я, $\epsilon$ не тільки погіршання екологічної ситуації, зниження рівня соціального забезпечення та медичної культури населення, стрімкий розвиток технічного прогресу, а й недостатні можливості загальноприйнятих методик виявлення патологічних станів на донозологічному етапі. За даними різних авторів, стан здоров'я та перебіг різних захворювань не може розглядатися без урахування процесів адаптації організму [2]. Фізіологічною сутністю адаптації $\epsilon$ сукупність функціональних механізмів, які забезпечують адекватне пристосування організму до впливу навколишнього середовища, гармонійний розвиток і збереження належного рівня параметрів гомеостазу [3].

Практично всі прояви пристосувальної діяльності організму пов'язані зі збільшенням навантаження на серцево-судинну систему, оскільки вона забезпечує органи і тканини киснем та енергетичним матеріалом.

У ході наукових досліджень встановлено, що рівень адаптаційних можливостей дитини формується не стільки наявністю певних відхилень у стані здоров'я, скільки індивідуальним функціональним резервом [4]. В цьому аспекті актуальним $є$ пошук факторів ризику, які спричиняють зниження пристосувальних можливостей серцево-судинної системи, що можуть впливати на стан здоров'я дітей та ефективних методів його поліп- шення. На нашу думку, серед цих факторів чи не найважливіша роль належить дефіциту йоду [5]. Відомо, що ЙД є важливим чинником відставання у фізичному розвитку, погіршення пам'яті, здатності до абстрактного мислення, зниженої опірності та витривалості організму.

Мета дослідження - вивчення адаптаційних можливостей школярів молодших класів міста Києва з підтвердженим ЙД.

Дослідження передбачало анкетування родини з питань поінформованості щодо наслідків йодного дефіциту; визначення йодурії у разових порціях сечі з подальшим розрахунком медіани; функціонального резерву серцево-судинної системи з визначенням індексу Руф'є (IP) (Наказ МО3 України № 518/674 від 20.07.2009) та її адаптаційного потенціалу (АП) з розрахунком Індексу функціональних змін (ІФЗ).

Матеріал і методи дослідження. Вміст йоду у сечі визначали перекисно-каталітичним напівкількісним методом, а результати оцінювали за критеріями ВООЗ /МРКЙДЗ (2001, 2007).

Розрахунок індексу Руф'є проводили за формулою:

$$
\mathrm{IP}=\frac{4(\text { ЧCC } 1+\text { ЧCC2 }+ \text { ЧСC3 })-200}{10} \text {, де: ЧСС1 - }
$$
частота серцевих скорочень за 15 с у стані спокою, чСС2 - частота серцевих скорочень за перших 15 с хвилини відновлення, чССЗ - частота серцевих скорочень за останні 15 с першої хвилини відновлення.

Навантаженням було 30 присідань за 45 с. Рівень функціонального резерву серцево-судинної системи оцінювали за 5 градаціями: менше 3 - ви- 
Огляди літератури, оригінальні дослідження, погляд на проблему

сокий рівень, 4-6 - вище середнього (добрий), 7-9 - середній, 10-14 - нижче середнього (задовільний), більше 15 - низький. Високий та вище середнього IP свідчать про задовільний резерв серцево-судинної системи.

ІФЗ розраховували за формулою:

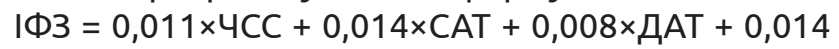
×вік + 0,0009×маса тіла -0,0009×зріст -0,27.

Результати досліджень оцінювали за модифікацією Л. В. Квашніної та співавт., адаптованої для дитячого віку: задовільна адаптація до 1,89, напруження адаптації від 1,9 до 2,14, незадовільна адаптація -від 2,15 до 2,41, зрив адаптації-вище 2,41 [6].
Результати й обговорення. Було обстежено 50 дітей віком 6-12 років в умовах Центру первинної медико-санітарної допомоги № 4 Деснянського району міста Києва. Найтиповішими скаргами обстежених дітей були зниження уваги, концентрації, працездатності, пам'яті, слабкість, підвищена втомлюваність. У 40 (77,2 \%) дітей був підвищений інфекційний індекс - вони хворіли на ГРВІ від 8 до 12 разів на рік, часто мали ускладнення у вигляді синуситу, пневмонії тощо.

На підставі проведеного дослідження йодну недостатність виявлено у більшої частини обстежених школярів (рис. 1).

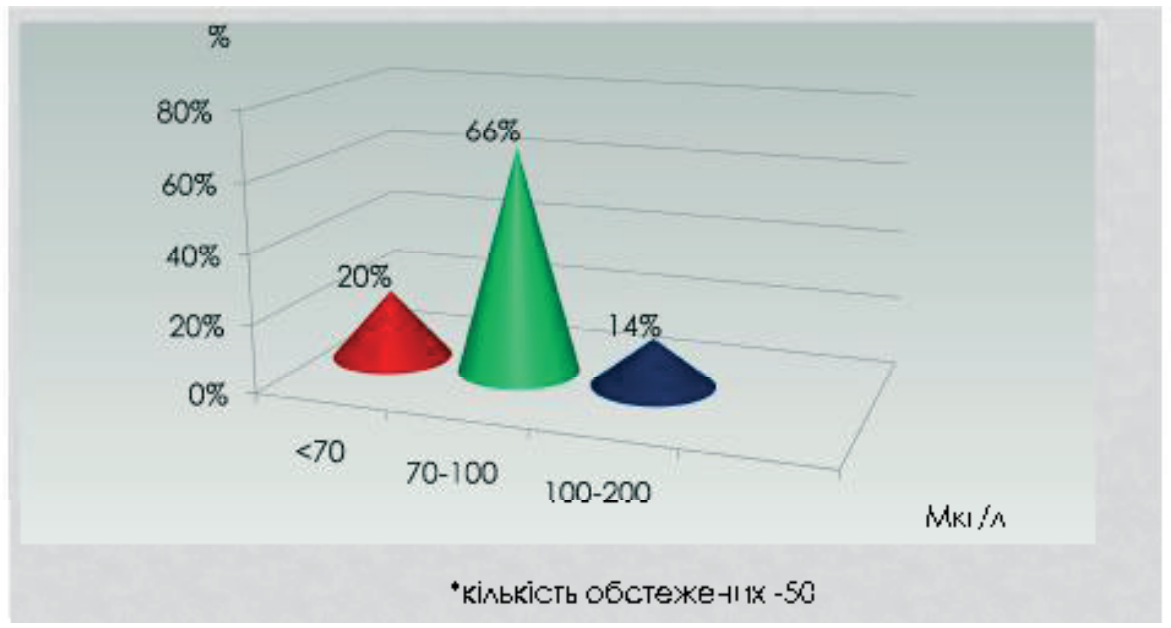

Рис. 1. Рівень йодурії у обстежених школярів.

У 33 дітей (66 \%) медіана йодурії була в межах 70-100 мкг/л, що є показником йододефіциту легкого ступеня. У 10 дітей (20\%) медіана становила менше 70 мкг/л, що відповідало Йд середнього ступеня тяжкості. У 7 (13 \%) дітей екскреція йоду з сечею була в діапазоні 100-200 мкг/л, що $\epsilon$ оптимальним показником. Результати анкетуван- ня показали, що ці діти вживали йодовану сіль або йодовмісні вітамінно-мінеральні комплекси.

При оцінці АП системи кровообігу виявлено, що тільки 10 \% дітей мали задовільну адаптацію. У більшості обстежених 38 (76 \%) відмічали напруження механізмів адаптації, у 7 (14 \%) дітей адаптація була незадовільною (рис. 2).

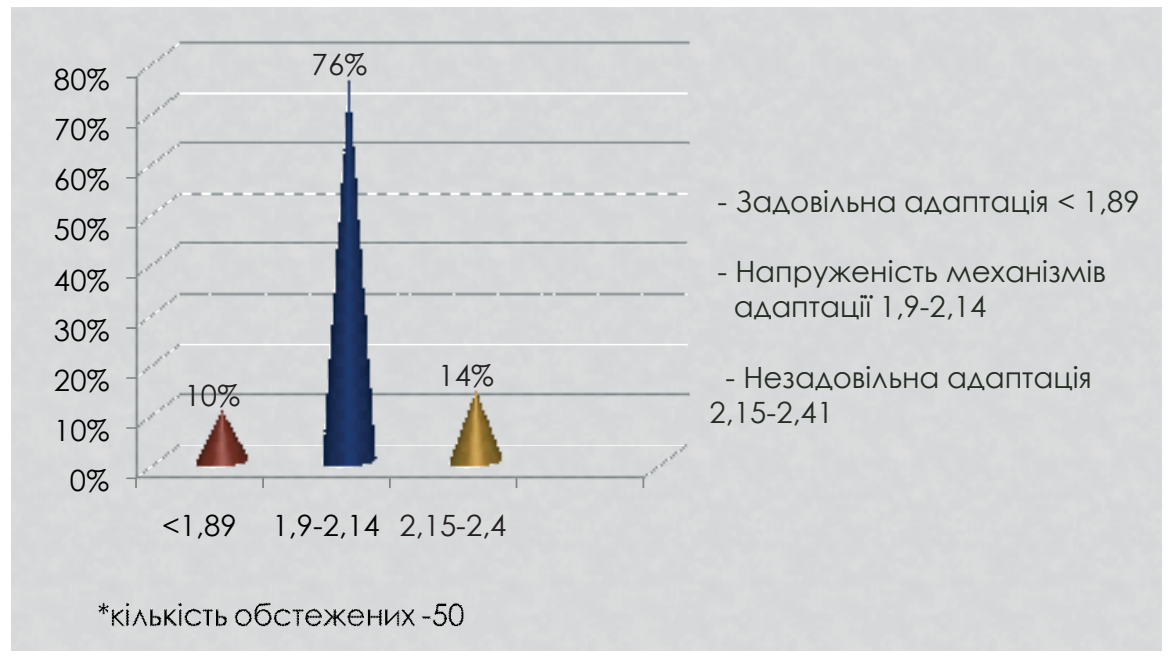

Рис. 2. Індекс функціональних змін. 
Огляди літератури, оригінальні дослідження, погляд на проблему

За даними Квашніної Л. В. [7], при проведенні скринінг-діагностики стану здоров'я школярів молодших класів (з невизначеним йодним забезпеченням) за допомогою ІФЗ переважав рівень задовільної адаптації - 55,2 \%, напруження адаптації відмічено у 31,5 \% дітей, незадовільна адаптація виявлена у 9,8 \% обстежених.

Таким чином, у школярів із зниженим йодним забезпеченням АП знаходиться, в основ- ному, у стані напруження, за винятком поодиноких випадків задовільних пристосувальних можливостей.

Поряд із зміненим функціональним станом адаптаційних реакцій, насамперед серцево-судинної системи, виявлено зниження ії резерву. Так, IP був нижче середнього у 16 дітей (32\%), низький рівень мали 29 дітей (58\%), у 5 (10\%) школярів він був на середньому рівні (рис. 3).

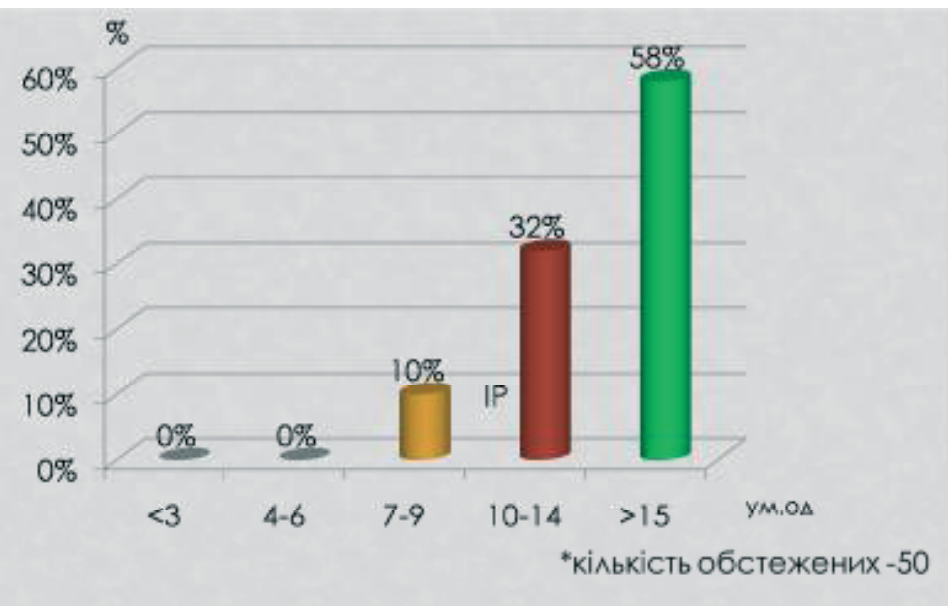

Рис. 3. Індекс Руф'є у обстежених школярів.

Дослідження останніх років, які проводили серед школярів цього ж віку (з невизначеним йодним забезпеченням) свідчать, що тільки у 19,8 \% дітей резерв серцево-судинної системи був достатнім (тобто високим і вище середнього IP) [8]. Серед дітей із зниженим йодним забезпеченням таких показників не було. Це вказує на низький рівень фізичної витривалості, що суттєво знижує довготривалу адаптацію до навантажень в умовах сучасної школи.

Наші дослідження показують, що практично в усіх дітей із ЙД легкого чи середнього ступеня тяжкості здатність адаптуватися або адекватно реагувати на діючий фактор, що демонструє реакція серцево-судинної системи, зокрема ії регуляторні механізми, порушена.

Згідно з літературними даними, йод, будучи невід'ємною складовою біохімічно активних сполук, у тому числі, тиреоїдних гормонів, бере участь у регуляції багатьох функцій організму: диференціювання тканин, процесів росту, ліполізу, метаболізму вуглеводів, синтезу білка та утворенні енергії. Саме тому серцево-судинна система, як найбільш енергетично залежна, першою реагує на зниження метаболічного забезпечення зниженням своїх функціональних резервів.
Висновки. 1. Дослідження йодної забезпеченості школярів віком 6-12 років м. Києва показало наявність ЙД легкого та середнього ступенів у $86 \%$ обстежених дітей.

2. При оцінці функціонального стану серцевосудинної системи виявлено, що більша частина дітей (76 \%) мали напруження механізмів адаптації, рівень задовільної адаптації виявлений лише у $10 \%$ випадків.

3. Індекс Руф'є у 90 \% школярів не відповідав достатньому резерву системи кровообігу.

4. Зміни функціонального стану та адаптаційних резервів серцево-судинної системи пов'язані певним чином із забезпеченістю організму йодом.

Перспективи подальших досліджень. Оцінка функціонального та резервного стану серцево-судинної системи дозволяє оцінити стан адаптації дитячого організму та спрогнозувати можливості розвитку патології, у тому числі щитоподібної залози, на донозологічному етапі. Діти, у яких за допомогою скринінг-тесту виявлена йодна недостатність, потребують поглибленого клінічного і лабораторно-інструментального обстеження не тільки щитоподібної залози, а інших органів. 
Огляди літератури, оригінальні дослідження, погляд на проблему

\section{ЛІТЕРАТУРА}

1. Стан здоров'я школярів в Україні / С. Л. Няньковський, М. С. Яцула, М. І. Чикайло, І. В. Пасечнюк // Здоровье ребенка. - 2012. - № 5 (40). - С. 109-114.

2. Бабій І. Л. Адаптаційні можливості школярів / І. Л. Бабій, В. І. Величко, Я. І. Венгер // Здоровье ребенка. -2011 . - № 8 (35). - С. 20-24.

3. Адаптаційно-резервні можливості організму дітей, хворих на бронхіальну астму / В. П. Костроміна, О. О. Речкіна, Л. Б. Ярощук [та ін.] // Астма та алергія. 2014. - № 3. - С. 13-19.

4. Шляхи підвищення рівня здоров'я дітей шкільного віку / В. П. Неділько, Т. М. Камінська, С. А. Руденок, Г. В. Скибан // Современная педиатрия. - 2010. № 3 (31). - С. 81-84.

5. Сорокман Т. В. Показники розвитку дітей шкільного віку, які проживають в умовах йодного дефіциту /
Т. В. Сорокман // Здоровье ребенка. - 2015. - № 2 (61). C. $83-87$.

6. Квашніна Л. В. Спосіб оцінки адаптаційних можливостей у дітей 6-17 років / Л. В. Квашніна, Ю. А. Маковкіна, Л. Г. Кузюк, А. В. Костенко// Опис до патенту на корисну модель № 26173 UA, A61B5/02; №u200703861; заявл. 06.04.2007; опубл. 10.09.2007. - Бюл. № 14.

7. Квашніна Л. В. Своєчасна діагностика здоров'я дітей: оцінка адаптаційних можливостей / Л. В. Квашніна, Ю. А. Маковкіна // Мистецтво лікування. - 2005. № 10 (26). - С. 12-15.

8. Сучасні особливості стану здоров'я дітей молодшого та середнього шкільного віку м. Києва / О. В. Тяжка, Т. В. Починок, Л. М. Казакова, О. А. Строй // Здоровье ребенка. - 2011. - № 4. - С. 41-44.

\section{ESTIMATING ADAPTIVE POTENTIAL IN KYIV SCHOOL CHILDREN WITH IODINE DEFICIENCY ○O. A. Stroy, L. V. Slipachuk, L. M. Kazakova, Yu. P. Reznikov O. Bohomolets National Medical University}

SYMMARY. The purpose of our study was to investigate of adaptive potential in Kyiv junior school children with found iodine deficiency.

The examination of 50 children aged 6-12 was carried out. That suggested determining ioduria in one-time urine portions followed by estimating the median, physical endurance in children and finding the Roofie index (RI), and also estimating the level of cardiovascular system and its adaptive potential with calculating functional changes index (FChI) in conventional units (points).

As a result of research iodine deficiency was found in most examined schoolchildren. The iodurine median was within the range of 70-100 mcg/l in 33 schoolchildren (66\%), which indicates mild degree of iodine deficiency (ID). In 10 children (20\%) the median was less than $70 \mathrm{mcg} / \mathrm{l}$ which indicates average degree of ID. In 7 children (13\%) the iodine excretion in urine within the range of $100-200 \mathrm{mcg} / \mathrm{l}$ which was the best result (the optimal result). According to the results obtained, cardiovascular system functional indicator (RI) was below the average (within the range between 10 and 14 points) in 16 children (32\%). 29 children (58\%) had the low level (over 15 points). In estimating FChl it was found that the most part of children (38,76\%) had adaptation mechanisms strain, and 7 children (12 \%) had insufficient adaptation level.

The study of iodine supply in Kiev schoolchildren aged 6-12 showed the content of mild and moderate degree of ID in $86 \%$ of children. Roofie index was below average and low in 45 children (90\%). Cardiovascular system functional indicator showed that the most part of children $(38,76 \%$ ) had adaptive mechanisms strain, the level of insufficient adaptation was $7 \%$.

KEY WORDS: children, adaptation, iodine deficiency. 